\title{
Evaluation of Harvesting and Seed Dormancy Overcoming Techniques in Hymenaea courbaril Germination
}

\author{
Leonardo Regnier ${ }^{1,2 a^{*}}$ \\ ${ }^{1}$ Institute of Biosciences, University of São Paulo, São Paulo, Brazil \\ ${ }^{2}$ Departmento de parques e áreas verdes 2 , Secretaria do verde e meio ambiente, São Paulo, \\ Brazil \\ aregnier@alumni.usp.br
}

\begin{abstract}
Keywords: Fabaceae; Forestry seeds; Germination; Jatobá; Pre-imbibition; Scarification; Seedling production
\end{abstract}

\begin{abstract}
Hymenaea courbaril is an endangered Brazilian native species. Recently, this species has been used on reforestation programs. So, production techniques that propitiate faster germination are very important. Although, seed dormancy, which could hamper the seedling production process, is not extensively recognized. Thus, this study focused on evaluating the influence of early harvest technique, scarification and pre-imbibition techniques to overcome $H$. courbaril seed dormancy in two steps. First, evaluating green fruits harvest could influence the germination process, 137 visually healthy seeds from green fruits and 400 seeds from mature fruits were selected. Seeds from green fruits presented similar results to seeds from mature fruits. Probably due to the natural seed tegument rupture. After, the influence of mechanical scarification, pre-imbibition and the combination of both methods were measured. All studied processing methods did not affect significantly any of the germination measurement parameters. Mechanical scarification exhibits similar responses as previous studies showed when using acid scarification. The technique of harvesting green fruits from the treetop seems to be applicable to commercial seedling production. While none of the studied treatments promoted significantly benefits to germination at any of the indexes.
\end{abstract}

\section{Introduction}

Nowadays more than one hundred million Brazilian people live in the Atlantic rainforest region, but the original vegetation is restricted to $7.3 \%$ of its original area [1]. This critic scenario associated with the attempt to recover the degraded areas has been promoting the interest and the need for scientific knowledge development concerning Brazilian native species [2].

The main problems found on native seedling production is the general pattern of slow development, especially to ecologic climax species [3]. Due to the long-term production of those species, the simpler techniques have not been able to provide adequate production to fulfill the reforestation program's demand [2]-[4]. Propitiating the development of techniques that generate higher quality seedlings and/or can reduce the time of the production process [3].

Hymenaea courbaril L. also known as "Jatobá" is a deciduous tree, with adult individuals of 20 meters long [5]. Presents wide geographic distribution due to its resistance to great climatic and hydric variations, and also its low nutritional requirements [6, 7]. Moreover, this species belongs to climax ecologic role, with slow development [1] and rare and irregular distribution on rainforests [7].

$H$. courbaril is economic relevant due to its main and worldwide use as a wood source to the civil construction and furniture fabrication, also resin extraction applied to varnish, incense, and fuel industry [1,7]. It is important in reforestation programs of degraded areas, and urban afforestation $[1,5]$.

This species population recovery in the natural environment seems to be slow and local restricted due to seed predation, and low survival of seedlings germinated in shaded environments [7]. These characteristics associated with the continuous and unbridled logging of this wood source had almost led this species to extinction $[8,9]$. 
Seed dormancy also hampers the seedling production process $[4,10]$. H. courbaril seed tegument impermeability is acquired after fruit fall, constituting the tegumentar dormancy [11], the most common dormancy type of Fabaceae family [10]. Affecting seedling production because seeds present low germination and large variations of germination rates between seed lots $[4,7,12]$. Some basic seed dormancy overcoming methods have already been indicated to this species [7, 12], [13]. Besides that, there is no information about its influences on germination, making possible to distinguish those different methods efficiency [12].

Scarification is the main method to overcome tegumentar seed dormancy, and have already been described as applicable to $H$. courbaril seeds, as well as the pre-imbibition method [1]. Associations of those methods have already been mentioned as a better option [1]. However, no further evaluations of its effects over $H$. courbaril germination have been done.

In some species, even green fruits can contain mature seeds, making the harvest of immature fruits an interesting procedure to reduce seedling production time. This technique, also known as early harvesting procedure, is cheaper since all fruits can be harvested at once, besides to enable longer transportation and avoid offering spoiled seeds or fruits to consumers [14]. However, this procedure could result in seed quality loss.

Therefore, this study aimed to evaluate techniques to reduce the required time for Hymenaea courbaril seedling production. Evaluating the harvesting of green fruits and also focusing on the main methods already described to overcome $H$. courbaril seed dormancy, the mechanical scarification, and pre-imbibition, tracking their influence on this species germination.

\section{Materials and Methods}

This study was conducted at the Harry Blossfeld plant nursery of São Paulo, situated in the city of Cotia $\left(23^{\circ} 36^{\prime} 30.0^{\prime \prime} \mathrm{S} 46^{\circ} 50^{\prime} 48.9^{\prime \prime} \mathrm{W}\right)$. The nursery presents an altitude tropical climate (Cwa) according to Köppen's climate classification [15]. Featuring concentered rains during summer, dry winter, and the highest mean temperature above $22^{\circ} \mathrm{C}[16]$.

Plant material was collected in the west region of São Paulo city from two populations, at two separated moments, the end of September and October both of 2018. Immature fruits were gathered directly from the treetop, while the mature has consisted of fallen fruits. Seeds were pulled out from fruits and cleaned; removing with a knife the endocarp adhered to seed tegument and funicular aryl, and then, washed with tap water. Only visually healthy seeds were selected to continue the experiment.

All material was kept in open plastic bags at room temperature for 5 days, seeking to dry the seeds, as recommended in Piña-Rodrigues et al. [17]. Before the beginning of experiments, a sample of 1000 seeds from mature fruits and 450 seeds from immature fruits were used to the estimation of mean weigh with a Filizola Mf weighing scale.

The study was divided into two steps. First, trying to evaluate if harvesting green fruits could influence the germination process, we used a sample of 137 seeds from visually green fruits and 400 seeds from mature fruits. The seeds were sowed in $280 \mathrm{~cm}^{3}$ greenhouse tube, with an organicbased substrate composed by 2 liters of local horizon B soil, 8 liters of rice husk, 5 liters of Basaplant ${ }^{\circledR}$ forestry substrate, $46.5 \mathrm{~g}$ of Yoorin $\mathrm{K} \AA$ potassium thermosetting fertilizer, and $46.5 \mathrm{~g}$ of gradual release fertilizer Osmocote Plus ${ }^{\circledR}$.

The second step consisted of the analysis of four treatments to overcome seed dormancy: scarification (with a sample of 108 seeds), pre-imbibition for 72 hours (sample of 152 seeds) and in the last two treatments the experiment was conducted with associations of both methods. In these last two methods, seeds were scarified and then submerged for 17 hours in tap water for the third treatment (using 189 seeds), or 72 hours in the fourth treatment (125 seeds sample). Seeds were planted in the same conditions and substrate of the first step. The second part of the experiment was conducted with seeds from mature fruits, and the control group procedure used in the first part was also used in this second part. The samples were divided into three repetitions of the treatments. 
After all treatments, the seeds were kept at greenhouse with white plastic covering and a fogging watering system with periodic activation every 35 minutes. Plant emergence was recorded during 70 days after seeding, with measurements nearly every 3 days.

All data were compiled to the Excel component of the Microsoft Corporation Office pack. Most usual germination indexes were obtained and statistically analyzed through GerminaQuant software [20]. The results were tested by ANOVA and in sequence submitted to the Tukey test with a critical $\mathrm{p}$-value of $5 \%(\mathrm{p}<0.05)$. The mean germination time, also known as the mean length of incubation time [18], was calculated as proposed by Haberlandt in 1875 [19]. All the other indexes were also calculated as recommended in Ranal \& Santana [18]. More information about the software statistical approach could be found in Lozano-Isla et al. [20]. Mean germination curves were represented through software R [21], using the ggplot2 package [22] with loess regression function.

\section{Results and Discussion}

\section{Seed weigh}

In forestry seeds, the estimation of mean seed weight is very important due to commercial applicability [23] since this kind of seed is usually sold per kilogram. In this study, mature seeds presented 186.22 seeds per kilogram. The mean seed weighs found (Table 1) was very discrepant from the value mentioned by Shanley [7] of 300 seeds per kilogram, and Campos et al. [23] of 295 seeds per kilogram. Although, this study information was consistent with the weight range of 2.1 and $6.5 \mathrm{~g}$ per seed mentioned by Costa et al. [1]. Those authors also found that $H$. courbaril seeds present a great variation of mass, especially because of the water content, which can represent from $9 \%$ until $12 \%$ of seed weight. This variation could explains the differences observed between other studies and this experimental data. The seeds from immature fruits contribute to this hypothesis since fresh seeds usually present greater water content, they usually present greater weigh, as suggested by this study data (Table 1).

Table 1. Mean weight of seed at different development stages before germination measurement

\begin{tabular}{cc} 
Seed development stage & Mean weight $(\mathrm{g})$ \\
\hline Mature & 5.37 \\
Immature & 6.58
\end{tabular}

\section{Harvesting method}

Harvesting immature fruits could influence seedling production, especially because it could affect the germination rate. In some species, even if fruits did not reach maturation, their content seeds have already completed the maturation process. In this case, it is not necessary to wait for the completion of the fruit maturation process, it is possible to harvest all the fruits, including the green ones, from the treetop. This procedure is also known as the early harvest. Other authors had already indicated that $H$. courbaril mature fruits can be harvested directly from the treetop [5], [24]. In general, the experimental data suggest that the seeds of $H$. courbaril from visually immature fruits presented a similar development pattern of seeds from mature fruits, presenting a slightly increased germination rate (Fig. 1- A). 
A

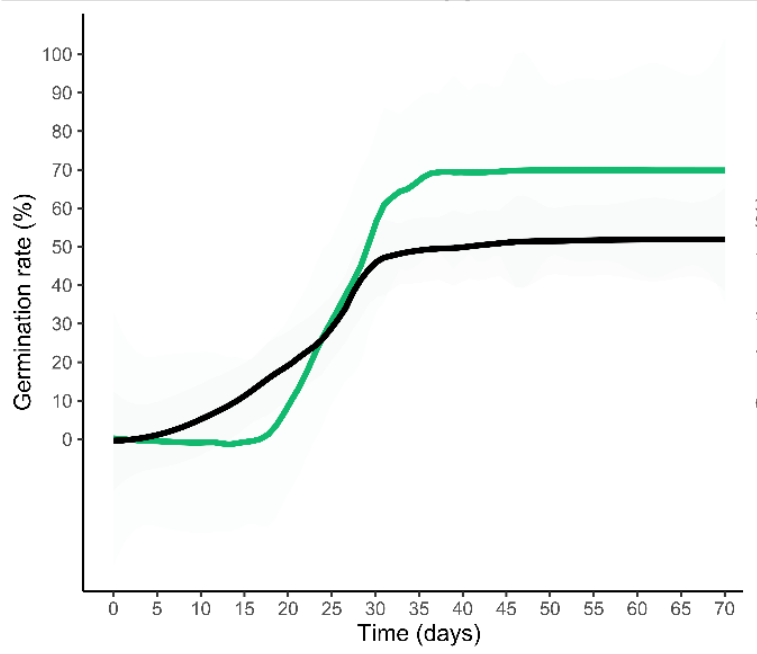

B

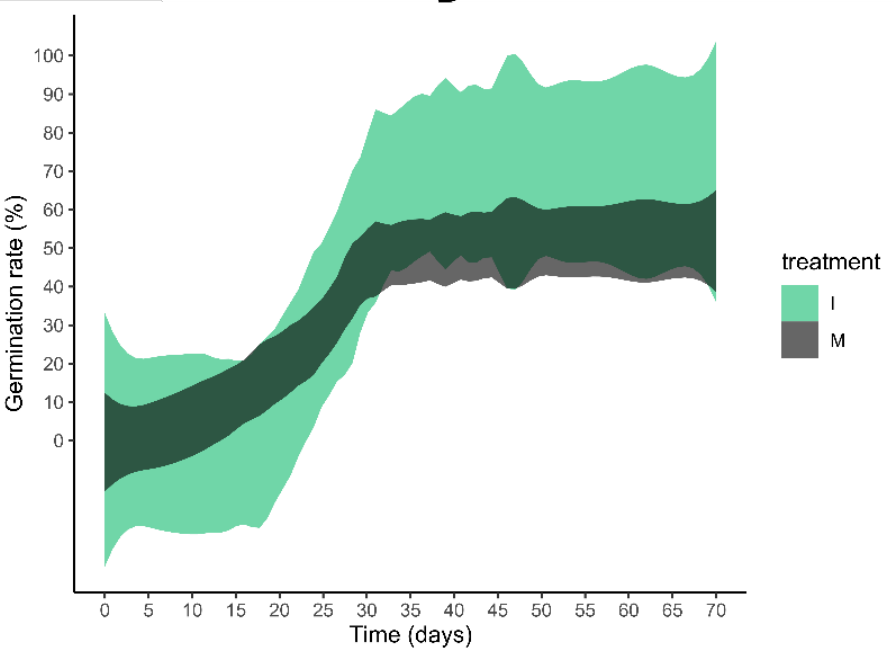

Figure 1. Cumulative emergence of Hymenaea courbaril represented through local regression (loess) of immature harvested fruits (I), and mature harvested fruits (M). A - Mean lines. B - Shadow representing the $95 \%$ Confidence interval

Melo et al. [11] have already noticed that the seeds of $H$. courbaril with greater water content have brittle tegument. During the drying period of 5 days adopted in the present study, the rupture of the seed tegument was conspicuous, especially to seeds from green fruits, but not so evident to seeds from mature fruits (Fig. 2). This fact emphasizes that the water content reduction during the drying period promoted the tegument rupture. Probably this susceptibility to tegument rupture impacts directly the seeds tegumentar dormancy. Other authors have already recognized that seed dormancy is highly variable between other Hymenaea species [25]. Cruz et al. [26] mentioned that in Hymenaea intermedia the seeds presented different dormancy degrees, and about $50 \%$ of them presented waterpermeable tegument. This present study data emphasizes that during the dry period, seeds tegument could rupture and naturally overcome seed dormancy. Resulting in variable degrees of tegumentar dormancy between the seeds of a seed lot, as found to Hymenaea intermedia [26], and as previously suggested to $H$. courbaril [27]. Possibly the tegument rupture is promoted during the dry season and propitiates seed germination when the rainy season starts.

In the natural environment, animal consumption of fruits also favors overcome the tegumentar dormancy of $H$. courbaril $[1,7]$. In general, at the natural environment, temperature variations, acid soil, microorganism metabolism and animal consumption of fruits are the main tegumentar dormancy overcoming methods [13]. Thereby, seed dormancy in $H$. courbaril seems to be naturally affected by dry periods and also animal interaction. 


\section{A}

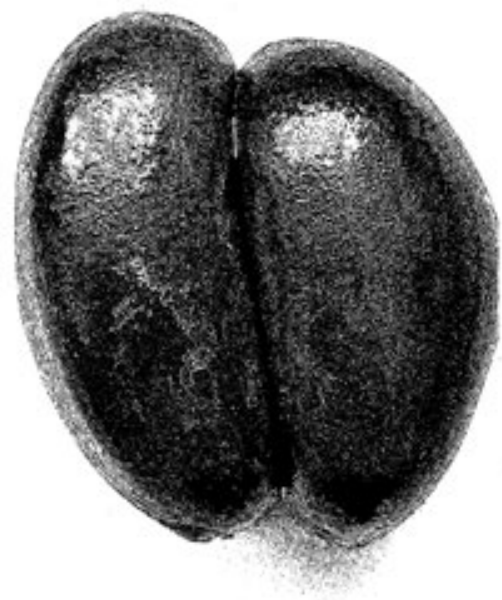

$0.5 \mathrm{~cm}$
B

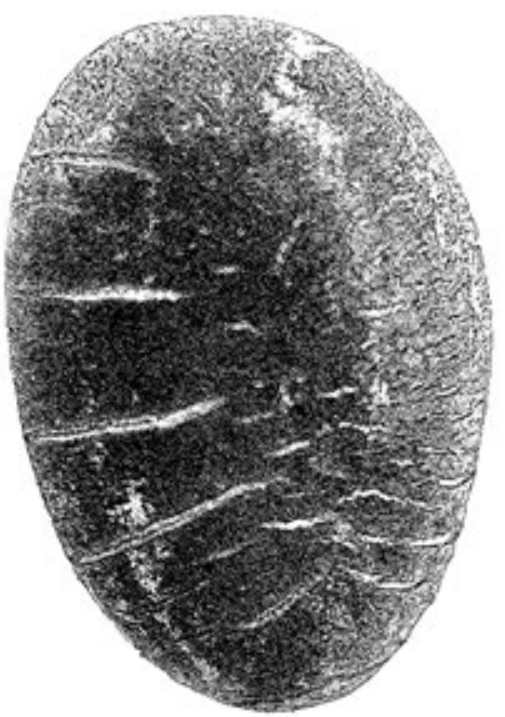

$0.5 \mathrm{~cm}$

Figure 2. Seed tegument aspect of Hymenaea courbaril: A - right after seed removal from fruit; B - the seed from immature fruit after 5 days storage at room temperature

The direct treetop harvesting technique in other studies, when applied to other Fabaceae species, indicated that this procedure could be not adequate for seedling production [10, 28]. Besides that, specifically to $H$. courbaril, it seems that there is no significant difference to seed quality when using this early harvest procedure. In general non-domesticated species could present variable maturation, and gathering fruits directly from the treetop could result in seeds with immature embryos, reducing the quality of a seed lot [10]. However, the results suggest that to $H$. courbaril seeds maturation seems to precede fruit maturation. Nevertheless, further investigations of this effect are necessary.

Even though the apparent highest values of seed germination proportion (GRP) found from seeds of immature fruits, there was no statistical difference between them (Fig. 3), and comparing the confidence interval (Fig. 1- B), it is important to notice the superposition of the curves. This effect is somehow expected because low water content could implicate in embryo death [23]. Water seems to be very important to $H$. courbaril development. Some studies have shown that seedling development is dramatically reduced in low water retention soils [6]. This could explain the slight reduction of germination to seeds from mature fruits since previous studies showed that they are drier than the seeds from green fruits as we also observed. Besides that, none of the indexes used in this study exhibited significant discrepancies between the harvesting methods. Indicating that the technique of harvesting green fruits from the treetop is applicable to seedling production, without affecting negatively the production. 

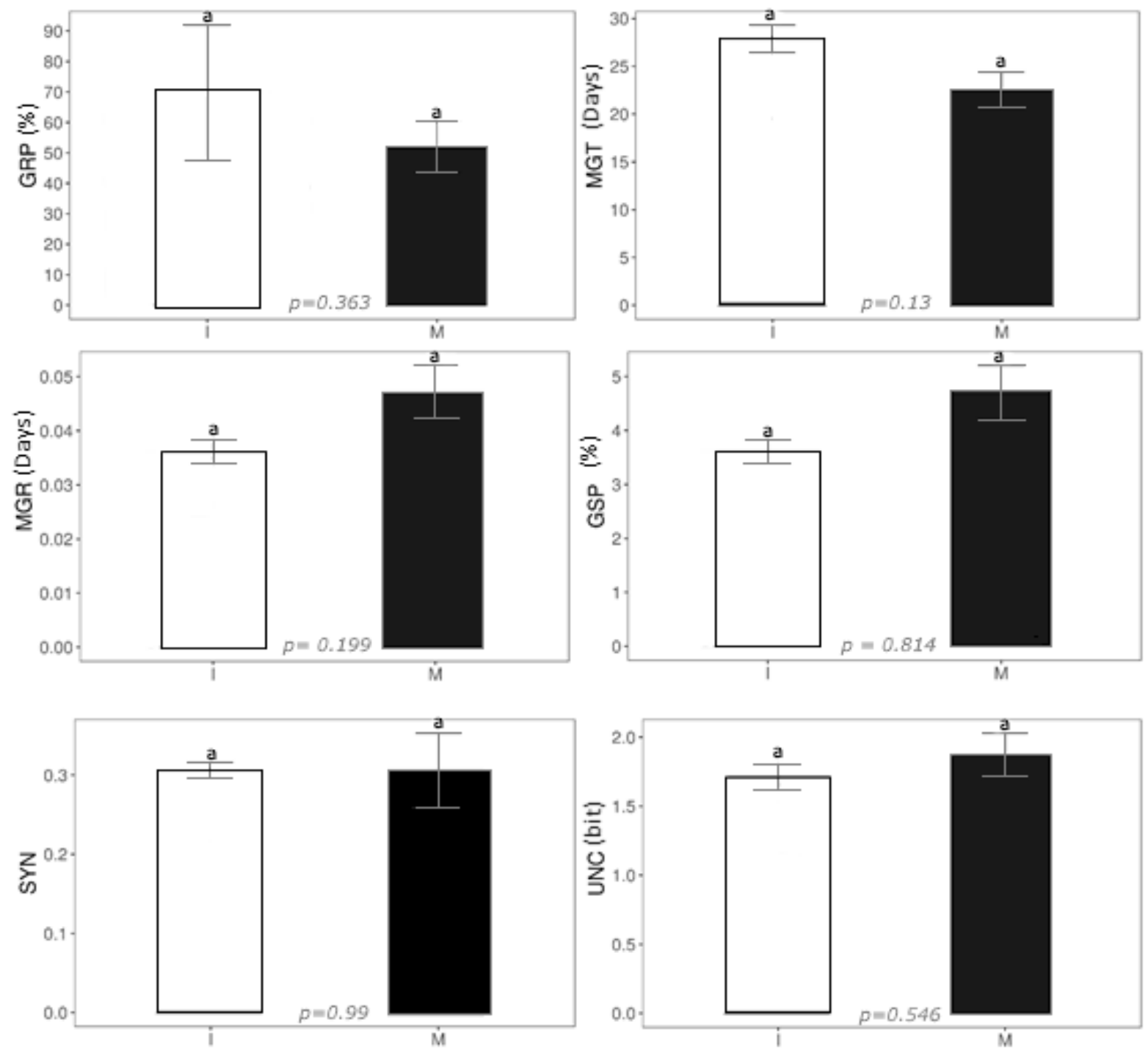

Figure 3. Germination Proportion (GRP), Mean germination rate (MGR), Mean germination time (MGT), Germination speed (GSP), Synchronization index (SYN) and Uncertainty index (UNC) according to the fruit development stage. Seeds from immature fruits (I) and seeds from mature fruits $(M)$. Lowercase letters present the statistical differences adopting $p<0.05$. Error bars present a standard error

The general pattern of non-cumulative germination also indicates great similarities between these harvesting methods (Fig. 4). Germination synchrony (SYN) is important to seedling production because of greater synchrony, that is, most seeds germinating at the same time, reduce the waiting time required to a seed lot to reach its maximum values of germination. Although, the data suggests there are no significant variations between the germination synchrony according to the fruit development stage. 


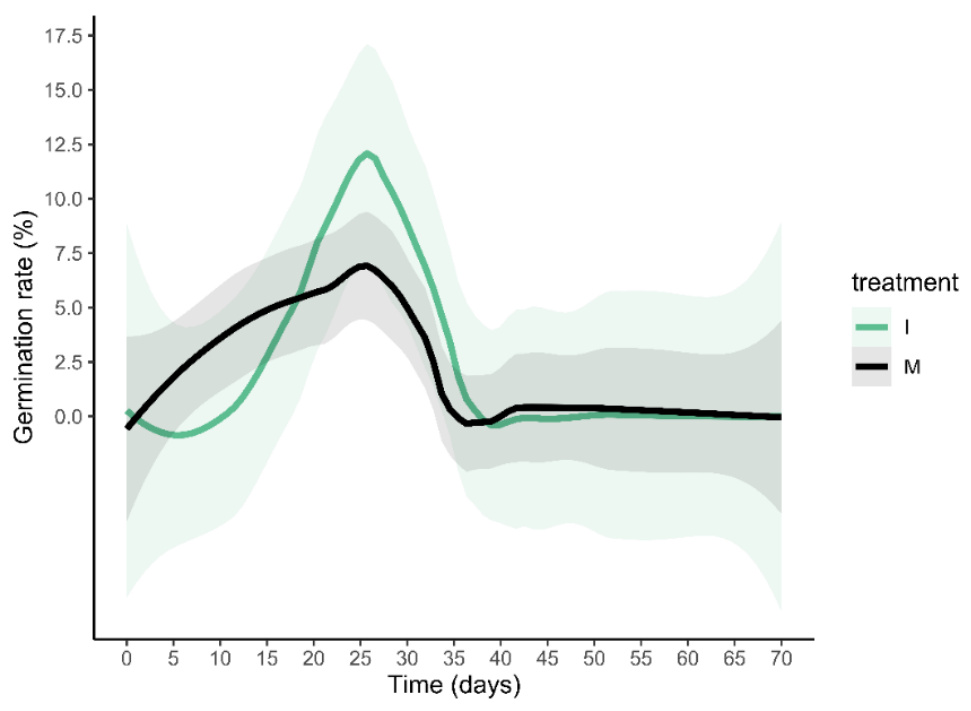

Figure 4. Non-cumulative emergence of Hymenaea courbaril seedlings of Immature harvested fruits (I), and mature harvested fruits (M)

Uncertainty Index (UNC) is an adaptation of Shannon ecologic diversity index [18, 20]. Thus, greater values indicate greater diversity and lesser synchrony of a seed lot germination. Seeds harvested from green fruits presented slightly reduced uncertainty index value, demonstrating subtly increased synchrony (Fig. 3). Non-cumulative germination data indicates that in green harvested fruits, there are concentrated germinations on the $28^{\text {th }}$ day after seeding (Fig. 4). This fact is possibly related to the tegument rupture observed at these seeds, because, without the integrity of the tegument, the imbibition process is facilitated. Promoting a tendency to more uniform germination of seed lot, since a greater number of seeds can concomitantly absorb water and recover embryo development. Besides that, the numerical difference was not significant. These aspects indicate that visual immature fruit harvesting did not negatively affect the germination, an important aspect focusing on seedling production.

\section{Seed dormancy}

The cumulative germination pattern between treatments was very diverse (Fig. 5). Apparently, all seed processing methods seemed to propitiate a better germination rate, compared to the control.

A

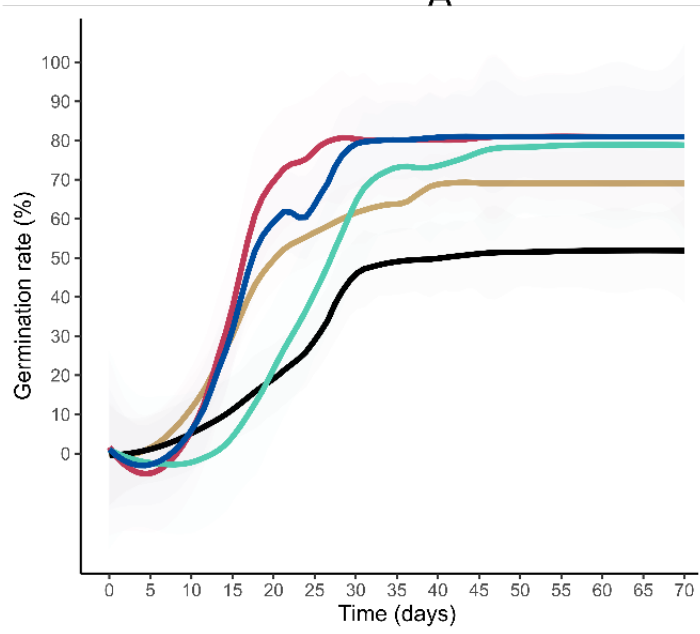

B

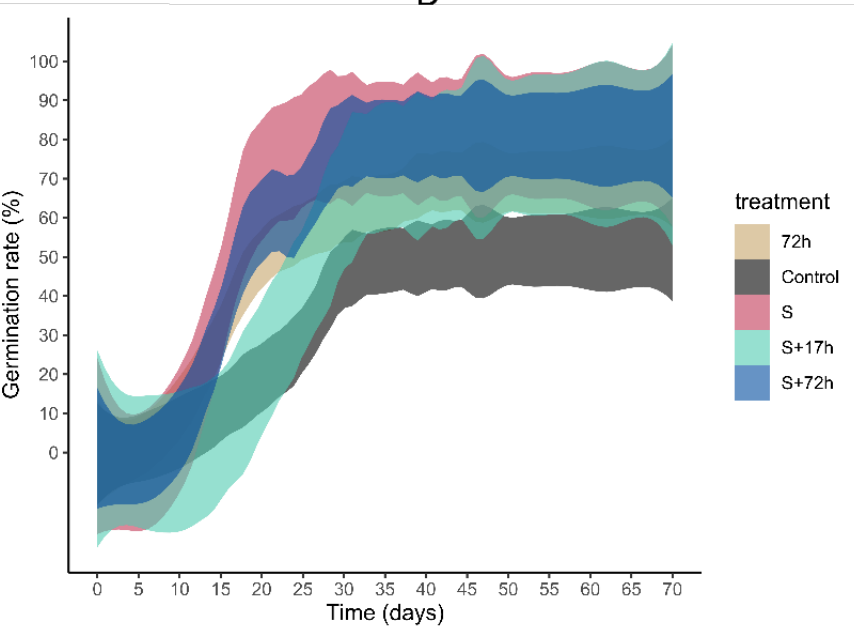

Figure 5. Cumulative emergence of Hymenaea courbaril represented through local regression (loess) according to the treatments: scarified seeds (S), 72 hours of pre-imbibition (72h), scarification and posterior 17 hours of pre-imbibition (S+17), scarification and 72 hours of preimbibition (S+72), and control (Control). A - Mean lines. B - Shadow representing the 95\% 
However, there were no significant differences between any harvesting methods and the control group (Fig. 6). All the indexes were not significantly affected. Observing the confidence interval (Fig. 6-B), the shadows overlap each other in most of the analyzed period. During this period, which curves are not overlaid, the analysis could indicate substantial differences. Although, a longterm analysis shows how this relevant discrepancy is reduced over time. Possibly due to great variations between the repetitions. As highlighted before, this fact reinforces the importance of a long-term approach to germination studies [29].

The time required to first emergences $\left(\boldsymbol{t}_{0}\right)$ of $H$. courbaril seeds comprehends a range from 12 [5, 12] up to 29 days [30]. This study data, about the control group, are consistent with the mentioned range ( $\boldsymbol{t}_{0}=22$ days) and with the values obtained to treatments (Fig. 5-A). Other authors affirm that seeds submitted to scarification or pre-imbibition start germination between 10 and 20 days $[24,30]$. In this study, when seeds were submitted to scarification and/or pre-imbibition, these values tend to slightly reduce comparing to control, but they remain in the time range presented by those authors.
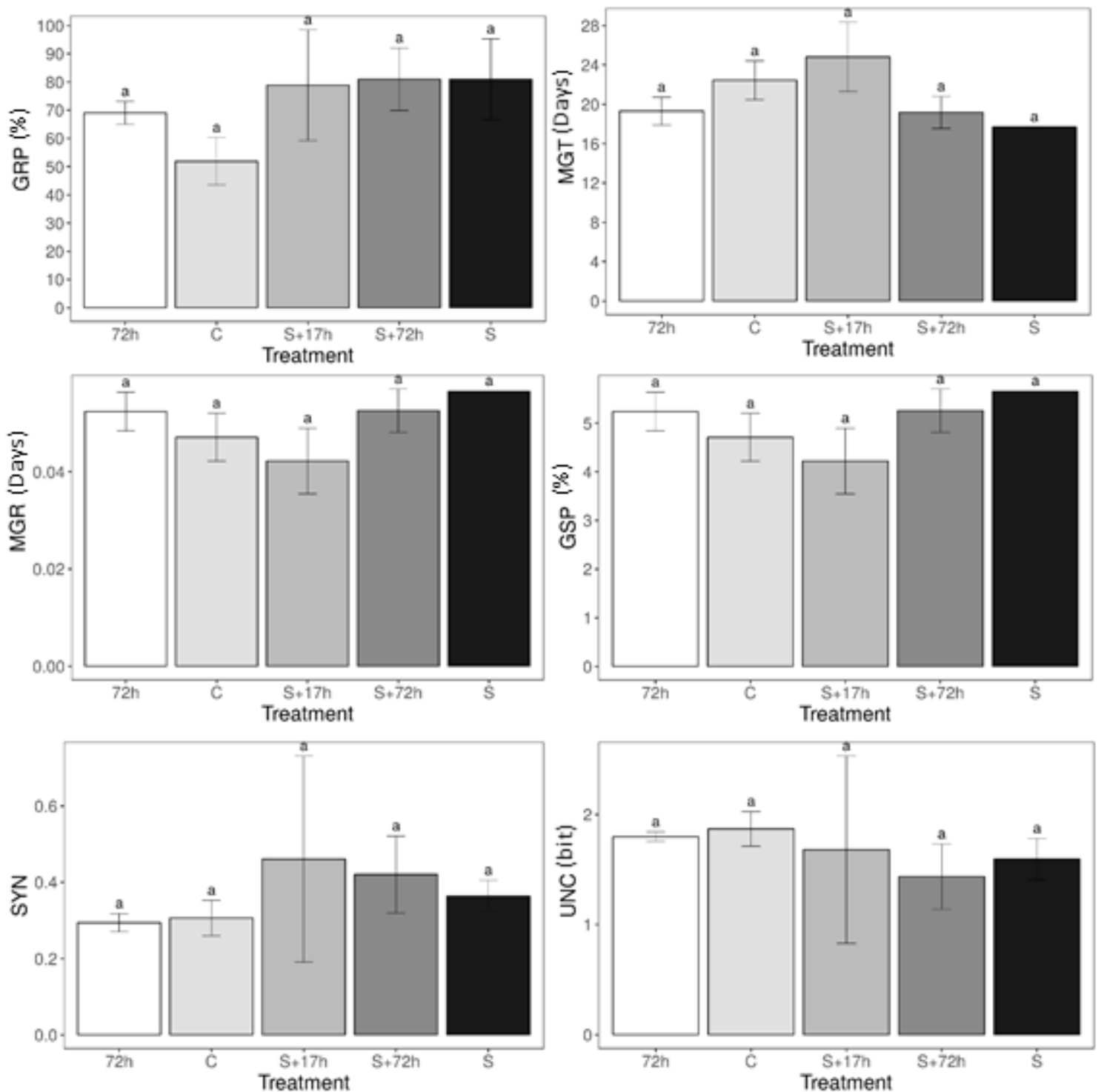

Figure 6. Germination Proportion (GRP), Mean germination rate (MGR), Mean germination time (MGT), Germination speed (GSP), Synchronization index (SYN) and Uncertainty index (UNC) according to the treatments: 72 hours of pre-imbibition (72h), control (C), scarification and posterior

17 hours of pre-imbibition ( $\mathrm{S}+17 \mathrm{~h}$ ), scarification and 72 hours of pre-imbibition $(\mathrm{S}+72 \mathrm{~h})$, and scarified seeds $(S)$. Lowercase letters present the statistical differences adopting $p<0.05$. Error bars present a standard error 
Mean germination time (MGT) to $H$. courbaril in this study was not significantly different between the control group and any of the studied procedures to overcoming seed dormancy (Fig. 6). Cruz \& Pereira [31] indicate that scarified seeds stabilize germination about 40 days after seeding and non-processed seeds about 679 days. While Carvalho Filho et al. [2] point out that non-processed seeds require 180 days to stabilize. These data are very discrepant from the results obtained to the present study (Fig. 5-A).

Brazilian native species present high regional variations, since they were not domesticated, and natural populations have been under evolutionary process influence, the differences between populations could be enormous depending on study sampling and species reproduction system [17]. In general, the previous studies evolving the efficiency of scarification and pre-imbibition have not been evaluating the association of those methods and conducting them concomitantly.

Besides that, important factors that could impact germination were not controlled. Those mentioned studies have not evaluated environmental conditions during the experiment and they were conducted at different climate regions. The water content in the soil and light exposure seems to affects the $H$. courbaril development $[6,32]$. Therefore, those discrepant data between experiments that do not control environmental conditions could be expected. Associated with that, the genetic reproduction system of $H$. courbaril is predominantly alogamic, which means that this species favors cross-fertilization, tolerating only about $10 \%$ of self-fertilization [17]. This reproduction system results in great diversity inside the same population than between populations [17]. This implicates that sampling from different populations does not necessarily propitiate a better representative sample. Although, this provides great variations between the seeds obtained from the same population [17]. Thus, besides the sample size bias is reduced in these species, $H$. courbaril responses seem to be diverse according to regional climatic variations.

Acid scarification in $H$. courbaril promotes germination rates higher than $90 \%$ [12]. The present study data also reached this mean germination rate, using mechanical scarification. Chemical scarification using acid compounds imposes some practical obstacles hampering its usage in seedling production, as those compounds are expensive, very difficult to manage when a large number of seeds are submitted to this process, and also individual's risk of accidents [10, 12]. While mechanical scarification using emery is a usual practice in the seedling production context, due to its safety practicality and low-cost [4]. Thus, evaluation of the mechanical scarification was important to understand if its effect over germination would be the same [12]. The experiment data indicate that mechanical scarification gets closer to the acid scarification germination rate. Although, there are great variations between repetitions, resulting in no statistical difference between this processing method and the control treatment. Similar results were also found in some acid scarification studies [33]. The high variability may be due to the reproduction system, providing great genetic variations inside the same population, and the seeds drying period storage could also be responsible for the observed differences.

Germination rate (GRP) also did not present statistical discrepancies between treatments. Similar results found by Cruz et al. [26] to $H$. intermedia, besides that, those authors found significant differences between scarified and control treatments to mean germination time. Differences we not found in this study. Germination rate to $H$. courbaril mentioned by other studies, considering seeds in natural conditions, varies between $89.5 \%$ [30] and 60\% [24]. Even the H. courbaril seed dormancy being extensively mentioned [5, 7, 24, 30], there was no clear documentation of its influence on germination. While some authors mention that besides the apparent hard tegument, $H$. courbaril presents fast germination [5]. Costa et al. [1] point that acid scarification seemed to promote better germination rates, but this author did not provide information about the harvesting process, the time between the seed harvesting and sowing or seed storage method. During the present study, seeds were stored for five days between seed gathering and the sowing procedure. After this period, seed tegument seems to be ruptured (Fig. 2) conspicuously in some cases. Thus, it is important to notice that if seeds are submitted to drying procedure before planting, as recommended by Piña-Rodrigues et al. [17], probably dormancy could be affected and this could influence the results. 
The recovery of the embryo development process occurs with seed hydration. It is dependent mainly on three factors: the seed reserve components, the difference of hydric potential between the seed and external medium, and temperature [34]. Scarification methods aim to attenuate or overcome the impermeability promoted by the seed tegument, enabling the contact with water and promoting imbibition, recovering the embryo development. While pre-imbibition procedure seeks to promote faster seed hydration by providing greater water support. The present study result indicates that there is no evident gain using these techniques to enhance germination. So there must be two possibilities to those results: seed tegument is not the main cause that hampers the imbibition phase or preimbibition methods adopted at this study was not appropriate to observe major differences. Thereby, those dormancy overcoming methods do not propitiate significative better results in seedling production.

During the experiment, events undocumented before could be noticed. Some seeds seemed to boldly attach to each other during embryo development, creating agglomerates (Fig. 2-A), in general of two, or, in rarer cases, tree seeds. In some of these agglomerates, all the components complete the development, as shown in Fig. 2-A. In this case, all seeds can germinate independently. But in some cases, one of the grouped seeds did not complete the development and only its aborted remains continue attached to the other seeds tegument. Plant albinism could also be noticed during the experiment, the observed frequency of albinism was $0.169 \%$ of all the seed lot used in this study.

\section{Conclusions}

Harvesting visually immature fruits from treetop seems to not influence germination. Seed dormancy overcoming methods of scarification and pre-imbibition up to 72 hours and their combination did not significantly affect any of the studied germination parameters. Thus, there was no clear enhance of germination with the sum of seed processing methods of scarification and preimbibition treatments.

\section{Conflict of Interest}

The author declares that there is no conflict of interest regarding the publication of this article.

\section{Acknowledgments}

I would like to appreciate Secretaria do Verde e Meio Ambiente, of São Paulo due to its trainee programs. In addition, the workgroup of Harry Blossfeld Municipal plant nursery, especially my trainee co-workers and Mr. Claudionor. My bosses Leila Borges Proença and Guilherme Brandão do Amaral for making this idea possible, which can make Brazilian's native plant production better. Also Rafaela C. Perez and Juliana de Lemos due to their consistent scientific support and encouragement.

\section{References}

[1] W. da S. Costa, A. L. de Souza, and P. B. de Souza, "Jatobá, Hymenaea courbaril L. - Ecologia, manejo, silvicultura e tecnologia," in Espécies Nativas da Mata Atlântica, vol. 2, Prospecção do Conhecimento Científico de Espécies Florestais Nativas (Convênio de Cooperação Técnica FAPEMIG / FUNARBE), 2011, pp. 1-21.

[2] J. L. de S. Carvalho Filho, M. de F. Arrigoni-Blank, A. F. Blank, and M. S. A. Rangel, "Produção de mudas de jatobá (Hymenea courbaril L.) em diferentes ambientes, recipientes e composições de substratos.," CERNE, 9(2003), pp. 109-118.

[3] A. de V. Ferraz and V. L. Engel, "Efeito do tamanho de tubetes na qualidade de mudas de Jatobá (Hymenaea courbaril L. var. stilbocarpa (Hayne) Lee et Lang.), Ipê-amarelo (Tabebuia chrysotricha (Mart. ex DC.) Sandl.) e Guarucaia (Parapiptadenia rigida (Benth.) Brenan)," Rev. Arvore, 35(3) (2011) pp. 413-423. 
[4] D. Ferraz, W. P. Ramalho, and L. S. R. Vale, "Methods for overcoming dormancy and seed storage of enterolobium contortisiliquum," Acta Sci. - Agron., 41(1) (2019) pp. 1-7.

[5] H. Lorenzi, Árvores brasileiras: manual de identificação e cultivo de plantas arbóreas nativas do Brasil. Nova Odessa: Plantarum, 2002.

[6] H. H. C. Nascimento, R. J. M. C. Nogueira, E. C. da Silva, and M. A. da Silva, "Análise do crescimento de mudas de jatobá (Hymenea courbaril L.) em diferentes níveis de água no solo," Rev. Arvore, 35(3) (2011) pp. 617-626.

[7] P. Shanley, "Jatobá: Hymenaea courbaril L.," in Frutiferas e plantas úteis na vida amazônica, P. Shanley and G. Medina, Eds. Belém: CIFOR, 2005, pp. 105-113.

[8] C. Pedroso-de-Moraes, T. de Souza-Leal, and P. Silveira, "Morfobiometria Carpo-Seminal, Superação De Dormência E Tratamentos Pré-Germinativos Com Ga3 Em Hymenaea Courbaril L. (Fabaceae)," Iheringia, Série Botânica, 73(3) (2018) pp. 221-227.

[9] M. F. Sampaio, S. R. do Couto, C. A. Silva, A. C. A. Silva, A. A. S. da Silva, and A. L. Teixeira, "Influência de diferentes substratos associados a métodos de superação de dormência na germinação e emergência de sementes de Jatobá (Hymenaea courbaril L.)," Farociência, 2(1) (2015) pp. 11-27.

[10] C. C. Martins, C. G. Machado, A. Martinelli-Seneme, and C. Zucareli, "Método de colheita e superação de dormência na qualidade fisiológica de sementes de Cassia ferruginea," Semin. Agrar., 33(2) (2012) pp. 491-498.

[11] M. G. G. da G. G. de Melo, M. S. de Mendonça, and Â. M. da S. Mendes, "Análise morfológica de sementes, germinação e plântulas de jatobá (Hymenaea intermedia Ducke var. adenotricha (Ducke) Lee \& Lang.) (Leguminosae-caesalpinioideae)," Acta Amaz., 34(1) (2004) pp. 9-14.

[12] A. A. Carpanezzi and L. C. T. Marques, “Germinação de sementes de jutaí-açu (Hymenaea courbaril L.) e de jutaí-mirim (H.parvifolia Huber) escarificadas com ácido sulfúrico comercial," in EMBRAPA CPATU, Circular T., Belém: EMBRAPA-CPATU, 1981, p. 15.

[13] A. G. de F. A. Sales, "Dormência, germinação e vigor de sementes de Parkia pendula (Willd.) Benth.ex Walpers e Samanea tubulosa (Benth.) Barneby \& Grimes," Universidade Federal Rural de Pernambuco- Forestry engeneering Department, 2009.

[14] J. B. C. da SILVA, L. de B. Giordano, O. Furumoto, and L. da S. Boitex, Cultivo de Tomate para Industrialização, 2nd ed. EMBRAPA Hortaliças, 2016.

[15] "SMA - Sistema de monitoramento agrometereológico," 2018. [Online]. Available: http://sma.fundacaoabc.org/climatologia/classificacao_climatica/sao_paulo. [Accessed: 20Oct-2018].

[16] D. L. O. da Silva and P. T. G. Gentili, "Riqueza de anuros no município de Cotia, SP," Anais do Conic-Semesp, vol. 1, Faculdade Anhanguera de Campinas - Unidade 3, 2013.

[17] F. C. M. Piña-Rodrigues, J. M. Freire, P. S. dos S. Leles, and T. B. Breier, Parâmetros Técnicos para a produção de Sementes Florestais, 1st ed. UFRRJ: Seropédica, 2007.

[18] M. A. Ranal and D. G. de E. Santana, "How and why to measure the germination process?," Rev. Bras. Botânica, 2 (2006) pp. 1-11.

[19] L. G. Laboriau, “A germinação das sementes,” Programa Regional de Desenvolvimento Científico e Tecnológico Série de Biologia, 1983.

[20] F. Lozano-Isla, O. E. Benites-Alfaro, and M. F. Pompelli, "GerminaR: An R package for germination analysis with the interactive web application 'GerminaQuant for R,", Ecol. Res., 34(2) (2019) pp. 339-346. 
[21] R Core Team, "R: A Language and Environment for Statistical Computing." R Foundation for Statistical Computing, Vienna, 2019.

[22] H. Wickham, ggplot2: Elegant Graphics for Data Analysis. New York: Springer-Verlag New York.

[23] M. V. A. Campos, N. V. M. Leão, E. S. C. Shimizu, A. D. D. de Freitas, and S. H. S. Felipe, "Atributos biofísicos de frutos e sementes e emergência de plântulas de Jutaí-açu," Enciclopédia Biosf. - Cent. científico conhecer, 15(27) (2018) pp. 124-132.

[24] C. Nogueira and P. H. S. Brancalion, Sementes e mudas: guia para propagação de árvores brasileiras. São Paulo: Oficina de textos, 2016.

[25] G. A. de Azeredo, R. de L. A. Bruno, L. A. de Andrade, and A. O. Cunha, "Germinação em sementes de espécies florestais da mata atlântica (Leguminoseae) sob condições de casa de vegetação," Pesqui. Agropecuária Trop., 33(1) (2003) pp. 11-16.

[26] E. D. Cruz, F. de O. Martins, and J. E. U. de Carvalho, "Biometria de frutos e sementes e germinação de jatobá-curuba (Hymenaea intermedia Ducke, Leguminosae Caesalpinioideae)," Rev. Bras. Botânica, 24(2) (2001) pp. 161-165.

[27] V. M. dos S. Souza and S. V. Segato, "Dormancy Break in Jatoba (Hymenaea Courbaril L.)," Nucleus, 13(1) (2016), pp. 71-80.

[28] L. Regnier, "Influence of Harvest, Processing, and Substrate in the Germination of Dalbergia nigra Seeds," J. Hortic. Plant Res., 5 (2019) pp. 30-37.

[29] L. de L. P. Regnier, "Germination analysis of Pterocarpus rohrii vahl under different sowing techniques," Int. J. Curr. Res., 11(2) (2019) pp. 1495-1499.

[30] E. D. Cruz and A. G. Pereira, "Germinação de sementes de espécies amazônicas: jatobá (Hymenaea courbaril L.)," Embrapa Amaz. Orient. Comun. técnico, 263, no. 1, pp. 1-5, 2015.

[31] D. C. De Farias, M. Eduardo, R. M. C. Mata, M. E. M. Duarte, and A. K. V. D. O. Lima, "Qualidade fissiológica de sementes de jatobá submetidas a diferentes temperaturas criogênicas," Rev. Bras. Prod. Agroindustriais, 8(1) (2006) pp. 67-74.

[32] K. M. O. Ramos, J. M. Felfili, J. C. Sousa-silva, C. W. Fagg, and A. C. Franco, "Desenvolvimento Inicial de plântulas de Hymenaea Stigonocarpa Mart. Ex. Hayne, sob Diferentes Condições de Sombreamento," Bras. Florest., 23(77) (2003).

[33] A. R. Freitas, J. C. Lopes, M. T. Matheus, L. H. G. Mengarda, L. P. Venancio, and M. V. W. Caldeira, "Superação da dormência de sementes de jatobá," Pesqui. Florest. Bras., 33(73) (2013) pp. 85-89.

[34] M. D. A. Guimarães, D. C. F. dos S. Dias, and M. L. Ehlers, "Hidratação de sementes," Rev. Trópica - Ciências agrárias e Bilógicas, 2(1) (2008) pp. 31-39. 